\title{
Sorvete Sabor Morango com Adição do Probiótico Bifidobacterium Bifidum ou Lactobacillus Casei
}

\author{
Claudia Dorta (II), Anna Claudia Sahade Brunatti (II), Flávia Maria \\ Vasques Farinazzi-Machado (II), Vanessa Pachelle Simão (II), \\ Ariele Cristina Viana dos Santos (II) \\ (II) Fatec Marília-SP - Fatec "Estudante Rafael Almeida Camarinha" Marília-SP (Av. Castro \\ Alves, 62, Somenzari, Cep: 17506000)
}

\section{Resumo}

Os alimentos funcionais são o foco para consumidores que procuram benefícios a saúde. O ramo que vem crescendo neste segmento é o de produtos lácteos adicionados de culturas probióticas, as quais promovem o bom funcionamento do intestino humano. Neste trabalho foram elaborados, junto à Gelateria Lunata (Marília-SP), sorvetes com adição de bactérias probióticas e verificou-se a manutenção de suas viabilidades celulares após processo e estoque. As bases dos sorvetes foram preparadas pelos colaboradores da sorveteria, e durante ou após a saborização destas adicionou-se os micro-organismos probióticos liofilizados na ordem de $10^{6}$ UFC/g, e em seguida foram submetidas ao congelamento aerado e armazenados em embalagens a $-23^{\circ} \mathrm{C}$ por até 60 dias. Quatro amostras de sorvetes foram feitas com sabor morango tendo as seguintes variações: adição de Bifidobacterium bifidum após liquidificador; de B. bifidum homogeneizado em liquidificador; de Lactobacillus casei e controle: sem adição de probiótico. Estas foram analisadas nos Laboratórios de Microbiologia e Físico-química da Fatec de Marília-SP, seguindo metodologias oficiais. As análises feitas foram: $\mathrm{pH}$, acidez total, viabilidade celular dos probióticos, coliformes totais, Escherichia coli e mesófilos aeróbios. Para os sorvetes com adição de B. bifidum testou-se in vitro sua resistência ao ácido clorídrico ( $\mathrm{pH}$ 2,0; 2,5 e 3,0 por $30 \mathrm{~min}$ ) e aos sais biliares $(0,3$ e $0,6 \%$ p:v). Os dados obtidos durante o período de 60

\footnotetext{
Referência:

Claudia Dorta, Anna Claudia Sahade Brunatti, Flávia Maria Vasques Farinazzi-Machado, Vanessa Pachelle Simão, Ariele Cristina Viana dos Santos.Sorvete Sabor Morango com Adição do Probiótico Bifidobacterium Bifidum ou Lactobacillus Casei. In: Anais do 12을 Congresso Latinoamericano de Microbiologia e Higiene de Alimentos MICROAL 2014 [= Blucher Food Science Proceedings, num.1, vol.1]. São Paulo: Editora Blucher, 2014. DOI 10.5151/foodsci-microal-001
} 
dias, quando necessário, foram submetidos à análise estatística. Verificouse que o $\mathrm{pH}$ e acidez dos sorvetes se mantiveram constantes. B. bifidum apresentou média de $10^{6} \mathrm{UFC} / \mathrm{g}$ durante 60 dias de armazenamento e mostrou-se resistente aos sais biliares, ácido clorídrico e ao oxigênio. A ingestão superior a $100 \mathrm{~g}$ deste produto atingiu quantidade superior a $10^{8}$ UFC por ingestão diária e está dentro da concentração estipulada para que exerça efeitos probióticos. Entretanto, L. casei mostrou menor viabilidade, sendo esta na ordem de $10^{5} \mathrm{UFC} / \mathrm{g}$, neste caso, seria necessária a adição de no mínimo $10^{7} \mathrm{UFC} / \mathrm{g}$ de sorvete. Os mesófilos aeróbios estavam dentro de limites recomendados. As amostras apresentaram coliformes totais e E. coli acima de limites estipulados por legislação, mostrando necessidade de ajustes nas práticas higiênicas na empresa de sorvetes.

Palavras-Chave: Gelado comestível, alimento funcional, Lactobacillus casei, Bifidobacterium bifidum, viabilidade celular

\section{Agência de Fomento:}

